\title{
Biofilm formation in persistent infections and its role in the pathogenesis of equine recurrent uveitis (ERU) - a literature review
}

\author{
Pina Geißler and Bettina Wollanke \\ Equine Clinic, Ludwig-Maximilians-University, Munich, Germany
}

\begin{abstract}
Summary: The formation of bacterial biofilm has gained increasing medical relevance in recent years. The involvement of biofilm has been demonstrated in a wide variety of chronic infections. Biofilm-associated infections are characterised by a chronic and recurrent course of disease, which is associated with immune-mediated tissue damage. The present literature review provides an overview of bacterial biofilm formation and presents its importance to biofilm-associated infections. The relevant pathophysiological mechanisms that occur in vivo during its formation are described by means of selected biofilm-associated infections. Equine recurrent uveitis (ERU) is a chronic disease of the equine eye caused by Leptospira and maintained by their persistence in the vitreous humour. Current research indicates that leptospiral biofilm might be involved in the pathogenesis of ERU. Biofilm bacteria are protected from the effects of the immune system and can be eliminated by antibiotics with great difficulty if at all. Chronic bacterial infections are, therefore, often associated with the formation of biofilms. The persistence of Leptospira in the vitreous humour triggers recurring bouts of inflammation, which damage the internal eye structures and, if left untreated, lead to blindness in horses. Intraocular biofilm formation might serve as a persistence mechanism since Leptospira can survive in the horse's vitreous humour and are capable of biofilm formation. When comparing ERU with biofilm-associated infections, such as chronic $P$. aeruginosa infection in cystic fibrosis patients or chronic wound infection, numerous similarities in the pathogenesis, diagnosis and therapy are evident. Recent investigations of vitreous material from affected horses have demonstrated leptospiral biofilm formation in the vitreous humour. The formation of biofilm in the equine vitreous humour might offer an explanation for both the persistence of Leptospira in the eye and the chronic recurrent pattern of the disease. Furthermore, the autoimmune phenomena observed in ERU might be explained by the presence of biofilm in the vitreous humour. Research on the aetiology of ERU and the involvement of intraocular leptospiral biofilm is still in progress. Future studies in the area of biofilm formation may provide further insights in the years to come.
\end{abstract}

Keywords: biofilm, biofilm-associated infection, equine ophthalmology, equine recurrent uveitis, ERU, Leptospira, intraocular biofilm

Citation: Geißler P., Wollanke B. (2021) Biofilm formation in persistent infections and its role in the pathogenesis of equine recurrent uveitis (ERU) - a literature review. Pferdeheilkunde 37, 225-233; DOI 10.21836/PEM20210303

Correspondence: PD Dr. Bettina Wollanke, Equine Clinic, Ludwig-Maximilians-University, Munich, Germany; b.wollanke@lmu.de

Submitted: April 1, 2021 | Accepted: April 23, 2021

\section{Introduction}

Bacterial biofilms have gained increased medical relevance over the past years (Høiby et al. 2011 ). Microorganisms can survive in a wide variety of environments, adapting to different growth conditions, due to their ability to form biofilms (Flemming and Wingender 2001). If biofilm formation occurs in vivo during bacterial infections, the immune system or antibiotic treatment can only eliminate the bacteria to a limited extent. This leads to chronic and recurrent courses of disease (Costerton et al. 1999, Lewis 2001).

Equine recurrent uveitis (ERU) is a chronic disease of the equine eye caused by leptospiral infection and characterised by recurrent episodes of inflammation (Wollanke et al. 2004). Existing literature on the topic of biofilm and biofilm-associated infections provides characteristics and common features of biofilm-associated infections that can be found in the pathogenesis, diagnosis and therapy of ERU (Geißler 2021).
A recent thesis has successfully demonstrated the biofilm formation of leptospires in the vitreous humour of affected horses (Ackermann forthcoming 2021). The vitreous cavity, with its framework of collagen fibrils, high water content and absence of inflammatory cells, provides ideal conditions for biofilm formation by migrating leptospires (Geißler 2021).

\section{Biofilms - a review}

Biofilms are defined as microbial communities that are attached to a substrate and surrounded by extracellular polymeric substance which is produced by the bacteria itself (Percival et al. 2011 ). Bacteria in biofilms exhibit an altered phenotype that differs in the growth rate and gene transcription from their planktonic counterparts (Donlan and Costerton 2002).

The formation of biofilm occurs following a common pattern (Figure 1). It starts with the initial attachment of bacteria to a 
surface and/or adjacent cells. As soon as the attachment to a (cell) surface is stable, microbial cell proliferation begins and microcolonies develop - triggered by chemical signalling pathways within the exopolysaccharide matrix. The cell density in the biofilm is controlled by quorum sensing, a process of intercellular signalling and cell-to-cell communication, and extracellular polymeric substance production is started, resulting in a three-dimensional biofilm structure. Water-filled interstitial cavities serve to transport nutrients and metabolites within the biofilm. The separation and scattering of biofilm parts occur by rapid cell proliferation in the marginal biofilm. The production of saccharolytic enzymes in this process facilitates the release of cells from the extracellular polymeric substance matrix. Bacteria are able to move to a new site of attachment by forming flagella (Jamal et al. 2018).

The biofilm matrix is largely composed of water (up to $97 \%$ ), a part of which is bound within the matrix. Additionally, water serves as a transport medium for nutrients, enzymes and metabolic products in interstitial cavities. Extracellular polysaccharides and proteins account for 2-4\% of the biofilm matrix and represent its key components. Carbohydrate-rich polymers enable the formation of a stable biofilm architecture and protect biofilm bacteria effectively from desiccation through their ability to bind water (Sutherland 2001). Matrix proteins with enzymatic properties are able to cleave other matrix components, thereby altering the biofilm structure. Furthermore, cell surface proteins, flagella and fimbriae contribute to the initial attachment, enabling surface colonisation (Fong and Yildiz 2015). Up to $2 \%$ of the biofilm matrix is composed of extracellular deoxyribonucleic acid (eDNA), ribonucleic acid, and cell detritus (Sutherland 2001). The eDNA are of either exogenous or endogenous origin. Exogenous eDNA is released by lysed polymorphonuclear leucocytes (PMNs) at infection sites and is then included in the biofilm matrix, whereas endogenous eDNA originates from the bacterial cells themselves and is released by cell lysis (Jakubovics et al. 2013). The eDNA contributes to a stable biofilm matrix by cross-linking bacteria-specific proteins and, thereby, forming a skeletal scaffold. The eDNA, for exam-

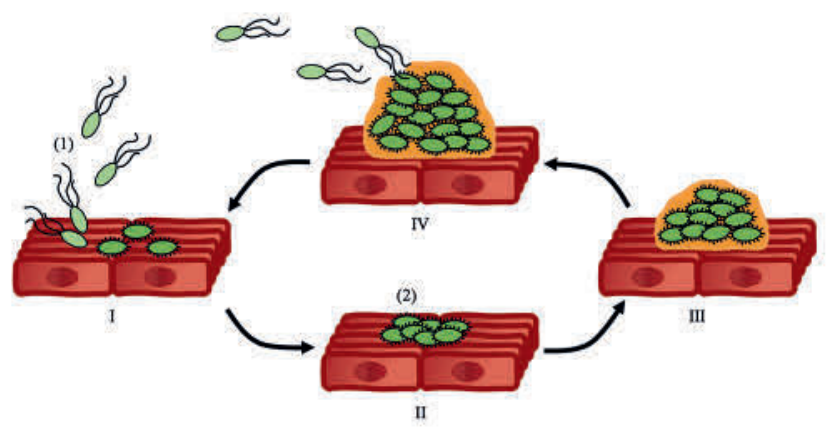

Fig. 1 Steps in biofilm formation - I. Initial contact and attachment to a surface; planktonic bacteria (1) develop their biofilm phenotype (2). II. Formation of microcolonies. III. Production of matrix components and biofilm development. IV. Dissemination of biofilm parts, release of planktonic bacteria | Schritte der Biofilm-Bildung I. Initialer Kontakt und Anhaftung an eine Oberfläche; planktonische Bakterien (1) gehen in den Biofilm-Phänotyp (2) über. II. Bildung von Mikrokolonien. III. Synthese von Matrix-Bestandteilen und Aufbau des Biofilms. IV. Ablösung von Teilen des Biofilms und Freisetzung planktonischer Bakterien. Reproduced from (Geißler 2021) ple, enables cross-linking of beta-toxin in S. aureus biofilms (Huseby et al. 2010). The eDNA within the matrix is able to bind cationic antibiotics through its negative charge, thus, protecting bacterial cells from antibiotic action (Chiang et al. 2013). In addition, secreted eDNA enables horizontal gene transfer (HGT), as eDNA in the matrix is part of a dynamic gene pool (Montanaro et al. 2011). Biofilms provide the ideal conditions for HGT due to their high cell density and accumulation of eDNA (Nagler et al. 2018).

\section{Biofilm-associated infections}

Biofilm-associated infections constitute a particular challenge to medicine due to their persistence and limited treatment options. The majority of bacterial infections are associated with biofilm formation - according to the National Institutes of Health, this affects $80 \%$ of bacterial infections in human medicine (Joo and Otto 2012). Biofilms typically cause chronic infections that persist despite seemingly adequate antibiotic therapy and immune responses. They are characterised by a persistent and progressive pathology that is maintained primarily by the inflammatory response in the environment of the biofilm. Persistent local inflammation is the only common feature of a wide variety of biofilm-associated infections, while other symptoms depend on the specific location and organ function (Hoiby et al. 2010, Hoiby et al. 2015). In the majority of cases, (surgical) removal of the biofilm and infected tissue is the only way to prevent a recurrence of the infection (Costerton et al. 1999, Dowsett 2013, Kinane et al. 2017).

Chronic $P$. aeruginosa infection in cystic fibrosis (CF) patients represents one of the most common biofilm-associated infections in human medicine. The CF is a monogenic, autosomal recessive, multi-organ disease caused by a defect in the $\mathrm{CF}$ transmembrane conductance regulator (CFTR) gene (Gibson et al. 2003). The CFTR defect leads to a production of dehydrated, viscous mucus in the lungs which is very difficult to clear from the airways (Donaldson and Boucher 2003). Consequently, mucociliary clearance is impaired and inflammatory defence mechanisms are activated (Gibson et al. 2003). Chronic recurrent bacterial lung infections occur and lead to irreversible lung tissue damage, especially due to permanent infection with P. aeruginosa (Biarnsholt et al. 2009). Due to high levels of oxidative stress in lungs of CF patients, $P$. aeruginosa establishes a mucoid phenotype (Mathee et al. 1999) characterised by an overproduction of the matrix component alginate, making the biofilm more sturdy and resistant to antibiotics and the immune system's effects (Hentzer et al. 2001). Alginate serves as a potent antigen, stimulating a great $\lg G$ and $\lg$ A antibody production, which is followed by immune complex-mediated destruction of the surrounding respiratory tissue (Bjarnsholt et al. 2009).

Chronic wounds are most commonly associated with bacterial colonisation and biofilm formation (James et al. 2008). The World Union of Wound Healing Societies suggests that the prevalence of biofilm in chronic wounds is almost $100 \%$ (Malone et al. 2016). Exposed subcutaneous tissue provides a moist, nutrient-rich environment and temperature that offers ideal conditions for microbial colonisation (Percival 2017). Bacterial strains most commonly isolated from infected 
wounds include S. aureus, P. aeruginosa, Proteus mirabilis, E. coli and Corynebacteriaceae (Bessa et al. 2015). If bacterial attachment and colonisation occur after primary contamination of the wound, the initial biofilm formation will only cause silent inflammation with subclinical symptoms (Percival and Cutting 2010, Percival 2017). As the biofilm continues to build, the release of exotoxins, quorum sensing molecules and eDNA increases, triggering the immune system's activation, which causes host tissue damage and results in delayed healing (Percival et al. 2012). Persistent inflammation in chronic wounds leads to an overproduction of slough, consisting of fibrin, pus, leukocytes, dead cells, microorganisms and proteins. These are predominantly by-products of the immune-mediated clearance of cellular debris and microorganisms (Percival and Suleman 2015). Cell lysis of PMNs is followed by a local release of proteolytic enzymes that have a pro-inflammatory effect and promote the influx of additional PMNs. Matrix metalloproteinases, neutrophil elastases and reactive oxygen species are increasingly released during chronic inflammation, causing damage to host proteins essential for wound-healing (Wolcott et al. 2008).

Biofilms are also assumed to be involved in veterinary bacterial infections. A biofilm-associated pathogenesis is, therefore, suggested for mastitis, wound infections, endometritis and pneumonia (Clutterbuck et al. 2007, Ferris et al. 2016, Ferris et al. 2017).

Criteria for biofilm-associated infections were presented by Parsek and Singh (2003):

- Infecting bacteria are bound to a substrate or surface.

- Direct examination of infected tissue reveals bacteria living in cell aggregates or microcolonies surrounded by extracellular matrix.

- Infection is generally confined to a specific localisation. Although bacterial dissemination may occur, it is a secondary phenomenon.

- The infection is impossible or difficult to eliminate by antibiotics, despite the responsible organism's sensitivity to the antibiotics applied in its planktonic state.

Two more criteria were added by Hall-Stoodley and Stoodley (2009):

- Culture-negative results, despite a strong presumption of an infection with the pathogen of interest.

- Ineffective immune response evidenced by bacterial cell aggregates surrounded by inflammatory cells in the host tissue.

In addition, the presence of chronic or recurrent infection itself has been proposed as a diagnostic criterion (Hoiby et al. 2010).

\section{Interactions with the immune system}

Chronic biofilm-associated infections are characterised by persistent inflammatory states that occur in a similar pattern among various diseases (Del Pozo 2018). Thereby, biofilm bacteria are able to maintain an excessive inflammatory re- sponse by producing pro-inflammatory cytokines, while disabling control mechanisms to protect excessive inflammation (Wolcott et al. 2008). P. aeruginosa utilises quorum sensing molecules that can affect host cells directly and induce the expression of pro-inflammatory cytokines (Jahoor et al. 2008). Continuous detachment of biofilm parts and planktonic bacteria can further bait the immune system and promote its response (Wolcott et al. 2008). S. epidermidis requires activated Aap protein for initial biofilm formation, which is proteolytically modified by host proteases and enables bacterial adhesion. In vivo effector mechanisms of innate immunity might, thus, induce cell aggregation and biofilm formation of $\mathrm{S}$. epidermidis directly and allow bacterial cells to protect themselves from elimination by phagocytosis (Rohde et al. 2005). The accumulation of $\lg G$ and complement factor $\mathrm{C} 3 \mathrm{~b}$ was reduced in studies with S. epidermidis, which may explain the lack of recognition by inflammatory cells (Kristian et al. 2008). In addition, the intracellular polysaccharide intercellular adhesin in S. epidermidis biofilms appears to provide protection against phagocytosis by PMNs (Vuong et al. 2004). A similar observation was made in P. aeruginosa biofilms: due to the matrix component alginate, $P$. aeruginosa cells were protected from interferon-gamma-mediated elimination by macrophages and from opsonization for phagocytosis (Pier et al. 2001). However, when parts of the biofilm are mechanically detached, macrophages are once again able to phagocytose the bacteria within (Thurlow et al. 2011).

A link between the occurrence of biofilm and the presence of neutrophil extracellular traps (NETs) has also been recognised in recent years. The NETs are released from activated PMNs in the presence of pathogens, consisting of DNA, granule proteins and antimicrobial peptides. They have been suggested to immobilise pathogens (Brinkmann et al. 2004). The NETs are thought to be released particularly when the pathogens cannot be eliminated by phagocytosis - biofilms seem to be a significant trigger for NET release in this context. The NETs, for their part, stimulate the production of biofilm, resulting in a positive feedback mechanism and the formation of a stable biofilm surrounded by large amounts of NETs (Papayannopoulos 2019).

\section{Interactions with antibiotics}

Bacteria in biofilms possess the best conditions for the development of resistance, tolerance and persistence due to protective substances in the matrix, their communication mechanisms and their ability to engage in genetic exchange. As a result, they are more difficult to eliminate by antibiotics than their planktonic counterparts (Hall and Mah 2017). When the innate resistance of biofilms to industrial biocides was first discovered, this phenomenon was attributed to poor penetration through the biofilm matrix (Costerton et al. 1987). However, it was later discovered that the matrix limits antibiotic diffusion only when matrix components react directly with the antibiotic (Stewart 1996). In P. aeruginosa biofilms, Psl is able to sequester certain antibiotics (Billings et al. 2013), whereas Pel appears to interact with eDNA in the matrix and, combined with eDNA, contributes to increased antibiotic resistance (Jennings et al. 2015). The eDNA serves as a protective shield for cells in the biofilm through antibiotic sequestration. Re- 
sistance to tobramycin and gentamicin reached a 2-3-fold increase in resistance levels by adding DNA to $P$. aeruginosa biofilms (Chiang et al. 2013). In addition to its physical role in protecting against antibiotics, eDNA plays an important role in the dissemination of resistance genes within the bacterial population in the biofilm through HGT (Hall and Mah 2017). Within the biofilm, differences in gene expression, metabolic activity and the phenotype of cells create physiological heterogeneity - triggered by oxygen and nutrient gradients (Stewart and Franklin 2008). Cells residing in hypoxic regions exhibit a reduced metabolic activity and maintain a state similar to the stationary phase of bacterial growth (Stewart et al. 2016). Moreover, the intercellular transfer of genetic material leads to an increased resilience against antibiotics within the biofilm. In addition to eDNA that can be scavenged from the matrix by competent cells, the conjugation of plasmids is also possible during HGT (Hall and Mah 2017). Savage et al. ( 2013) demonstrated that the conjugation frequency of a multiresistant plasmid of S. aureus was 104-fold higher in S. aureus biofilm than in planktonic cultures. Furthermore, an increased mutation frequency is observed in biofilms, as cells in biofilms are frequently exposed to oxidative stress, making them more prone to DNA damage and mutation (Boles and Singh 2008).

\section{Equine recurrent uveitis}

ERU is a chronic disease of the equine eye, which is caused by leptospires that persist in the vitreous cavity and cause recurrent episodes of inflammation (Gerhards and Wollanke 2001, Wollanke 2002, Wollanke et al. 2004). ERU is considered to be one of the most significant ocular diseases in horses and has been described as the major cause of their loss of vision (Deeg et al. 2002a, Gilger and Michau 2004, Gilger and Deeg 2011).

The majority of horses are thought to have become infected with leptospires at a young age (Wollanke 2002). If protective antibodies are produced at an early age, intraocular infection can be prevented - depending on the leptospiral virulence and the infectious dose (Wollanke et al. 2004). If the leptospires enter the eye, they can persist there for months to years without triggering an inflammatory reaction (Williams et al. 1971, Wollanke et al. 2004). Immunosuppressive intraocular mechanisms may play a role in this process, since the eye, as an immunologically privileged site, can repress exuberant immune responses effectively. During this phase, pathogens are assumed not to be adequately recognised and eliminated in the eye (Wollanke 2002, Wollanke et al. 2004, Gilger and Deeg 2011 ). The detection of leptospiral biofilm in the vitreous humour (Ackermann forthcoming 2021) is very likely to provide significant insights into the pathogenesis of ERU.

It has not yet been conclusively clarified how leptospires trigger the recurrent episodes of uveitis. However, previous research clearly depicts that uveitis leads to a breakdown of the blood-ocular barrier, whereupon immunocompetent cells can invade the interior of the eye. The balance between immunosuppressive and immunostimulatory mechanisms is disturbed and excessive immune reactions occur, which damage the ocular structures (Deeg et al. 2002b, Wollanke et al. 2004, Gilger and Deeg 2011 ). Leptospires which persist in the vitreous humour after the inflammatory episode appear to remain hidden from the immune system between the inflammatory episodes (Wollanke 2002).

Vitrectomy and, thereby, removal of the leptospires causative for ERU achieve absence of recurrence in up to $98 \%$ of horses (Wollanke et al. 2004, Schinagl 2017, Baake et al. 2019, Voelter et al. 2020).

ERU is described by some authors as an autoimmune disease and not associated with ocular leptospiral infection. The involvement of ocular autoantigens (retinal S-antigen and interphotoreceptor retinoid-binding protein in the autoimmune inflammatory responses of ERU supports this hypothesis (Deeg et al. 2001, Deeg et al. 2002a, 2002b, Deeg 2008). This, however, does not rule out leptospiral infection as a primary cause because infection-associated autoimmune phenomena occur in various diseases (Wollanke et al. 2004).

\section{Biofilm formation in the vitreous}

Leptospires are gram-negative, helical bacteria that use rotating motions to move in liquid media and penetrate tissues (Goldstein and Charon 1988). They form biofilm (Ristow et al. 2008) and use this ability as a persistence mechanism to allow the survival and spreading of pathogenic leptospires in the environment (Vinod Kumar et al. 2016). Cell aggregates of leptospires in the renal tubules of chronically infected mice further suggest that they are also capable of biofilm formation in vivo (Yamaguchi et al. 2018).
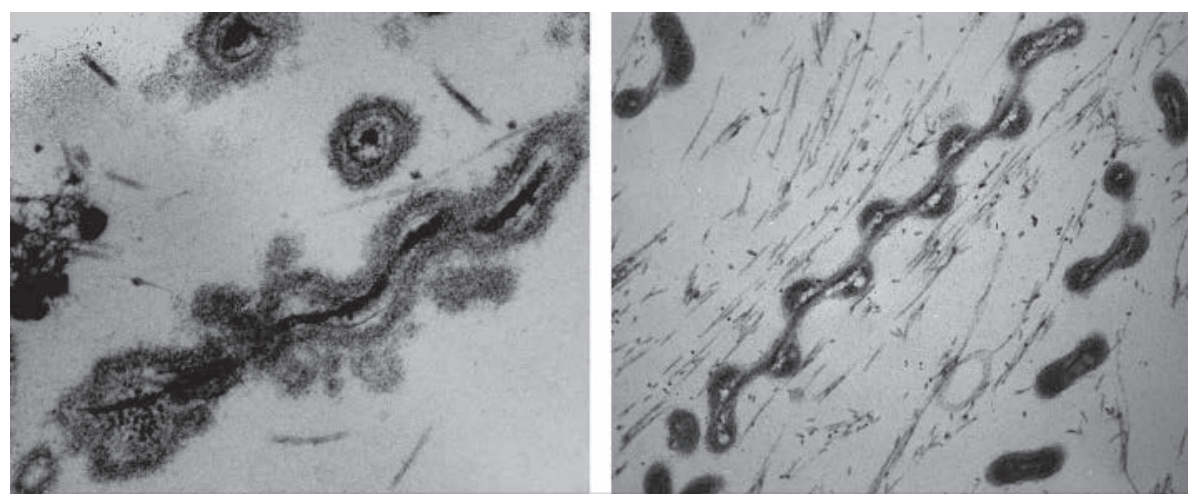

Fig. 2 Electron microscopic imaging of leptospires from vitreous samples - Left: Illustration of leptospires (and sections) from the vitreous material of horses suffering from ERU. A granular substance is visible on the cell surface. Right: Illustration of cultured leptospires after an experimental injection into a healthy equine eye. The cell surface appears smooth and without any deposits | Elektronenmikroskopische Darstellung von Leptospiren aus Glaskörperproben - Links: Darstellung von Leptospiren (-anschnitten) aus Glaskörpermaterial an ERU erkrankter Pferde. Auf der Zelloberfläche ist eine feinkörnige Substanz zu erkennen. Rechts: Darstellung von Kultur-Leptospiren nach experimenteller Injektion in ein gesundes Pferdeauge. Die Zelloberfläche erscheint hier glatt und ohne Auflagerungen (Niedermaier 2000) 
Studies examining samples of aqueous humour and vitreous material from ERU-diseased horses have demonstrated that leptospires reside in the vitreous humour as part of their persistence in the equine eye (Wollanke et al. 2004). Numerous surface proteins allow binding to host tissues - including various types of collagen and glycosaminoglycans (Murray 2015). Thus, binding to components of the vitreous body might be possible (Bishop 2000, Geißler 2021). As has also been described for leptospiral biofilm in aquatic systems, this attachment to a part of the vitreous humour, such as the vitreous fibrils, could constitute the first step of biofilm formation in the equine eye (Vinod Kumar et al. 2016, Geißler 2021).

Transmission electron microscopy studies examining vitreous material from affected eyes show leptospires surrounded by a granular material (Figure 2, left). The latter cannot be detected in cultural leptospires that have been experimentally injected into a healthy equine eye (Figure 2, right). The material, therefore, appears to be formed only during the persistence of the leptospires in the eye (Niedermaier 2000, 2002). Further studies found round structures of high density, some of which phagocytised by macrophages (Figure 3) (Brandes, 2006). Scanning electron microscopy also revealed spherical structures in ERU vitreous humour samples from which filamentous leptospiral structures protrude (Figure 4). Images of mature leptospiral biofilm in vitro appear as budding-like structures (Figure 5) (Thibeaux et al. 2020). Ristow et al. (2008) demonstrated the formation of leptospiral biofilm in different stages,

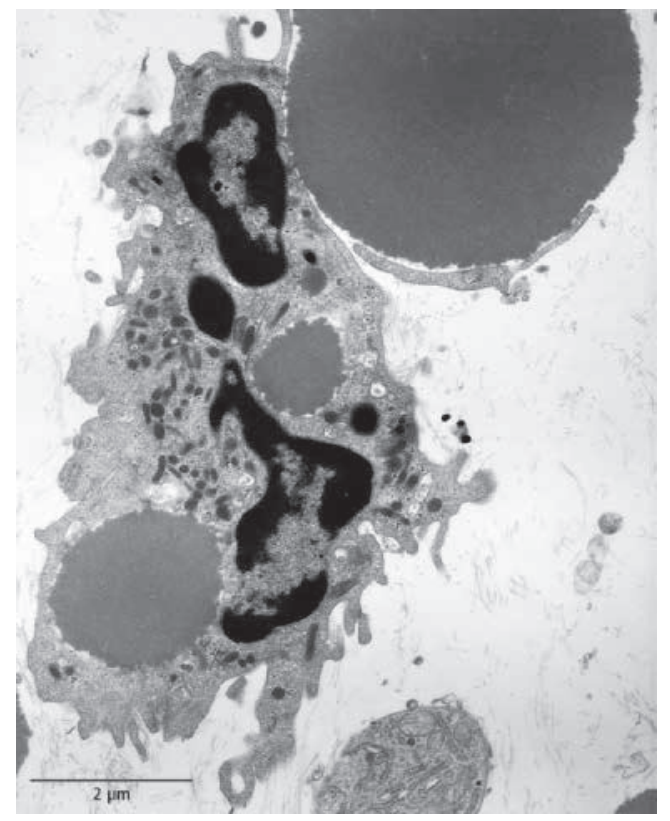

Fig. 3 Transmission electron microscope image of a vitreous humour sample from an eye affected by ERU. Small roundish and elongated structures are visible within the macrophage, which are presumably leptospires. In addition, two roundish structures of different sizes and high density are visible, which were probably phagocytosed. At the top right of the image, a third and larger roundish structure is visible, which the phagocyte apparently also wants to eliminate | Transmissionselektronenmikroskopisches Bild einer Glaskörperprobe aus einem an ERU erkrankten Auge. Innerhalb des Makrophagen sind kleine rundliche und längliche Strukturen erkennbar, bei denen es sich vermutlich um Leptospiren handelt. Zusätzlich sind zwei unterschiedlich große und sehr dichte rundliche Strukturen erkennbar, die vermutlich phagozytiert wurden. Oben rechts im Bild ist eine dritte und größere rundliche Struktur erkennbar, die der Phagozyt offenbar ebenfalls eliminieren möchte. (Brandes 2006) showing densely packed, roundish cell aggregates surrounded by biofilm matrix from which numerous leptospires protrude. When compared with the spherical structures from vitreous samples, a clear similarity can be observed. It is, therefore, assumed to be leptospiral biofilm formed in the vitreous body (Geißler 2021).

The detection of NETs in vitreous samples from ERU-diseased eyes (Fingerhut et al. 2019) may further support the theory of intravitreal biofilm formation, as the presence of in vivo

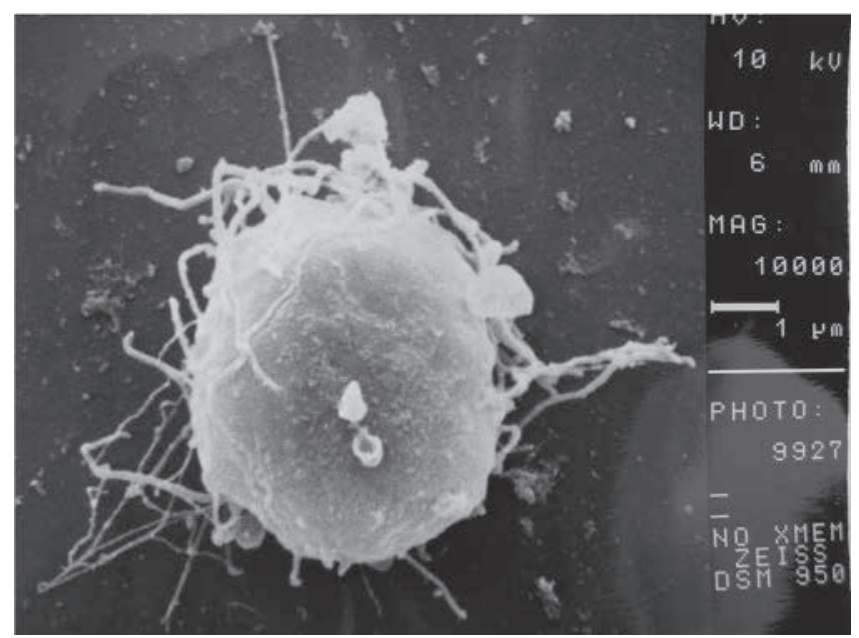

Fig. 4 Scanning electron microscope image of a vitreous sample from a horse suffering from ERU - Spherical structure with filamentous leptospiral structures protruding from them. This may be leptospiral biofilm (Fig. 5 for reference) | Rasterelektronenmikroskopische Darstellung von ERU-Glaskörperproben. Kugelförmige Strukturen, aus denen fädige, Leptospiren-ähnliche Strukturen hinausragen. Möglicherweise handelt es sich hier um Leptospiren-Biofilm (vgl. Abbildung 5). (Wollanke 2020)

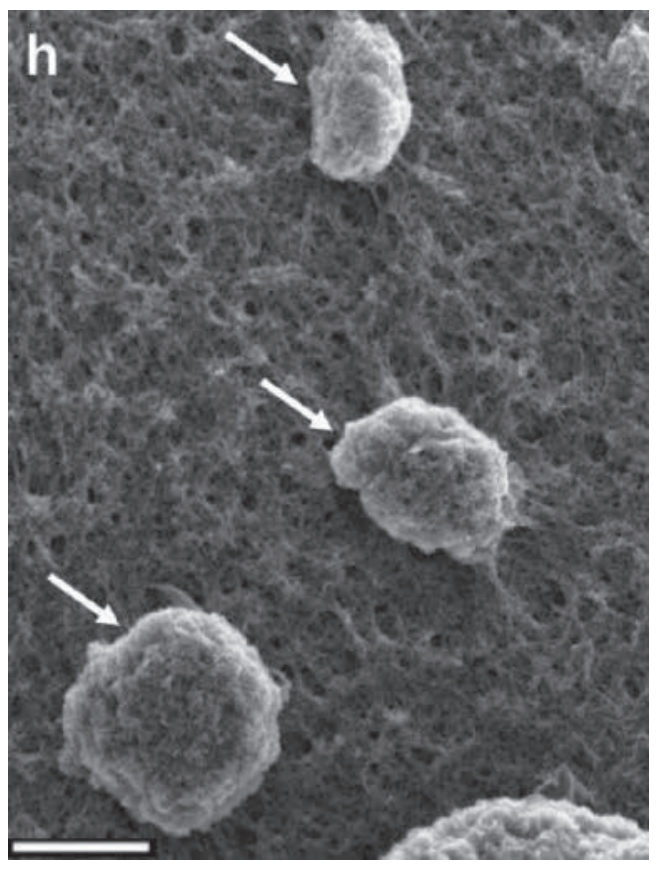

Fig. 5 Budding-like structures representing leptospiral biofilm in vitro. Scale bar: $20 \mu \mathrm{m}$. | Knospenartige Strukturen, die Leptospiren-Biofilm in vitro darstellen. Maßstab: $20 \mu \mathrm{m}$. Reproduced from (Thibeaux et al. 2020): "Leptospira biofilm architecture and organization" (Fig. 2, left panel), https://www.nature.com/articles/s41522020-0134-1, licensed under CC BY 4.0 
biofilm is considered to be associated with the occurrence of NETs (Papayannopoulos 2019).

\section{ERU as a biofilm-associated infection}

The general attributes of biofilm-associated infections (Parsek and Singh 2003, Hall-Stoodley and Stoodley 2009) can be found almost entirely in the pathogenesis of ERU (Geißler 2021):

- Infecting bacteria are bound to a substrate or surface. - The binding of leptospires to a substrate or surface in the eye has not yet been demonstrated. However, intraocular leptospires are thought to reside in the vitreous humour, where they can 'hide' from the immune system in the framework of vitreous fibrils. Therefore, a binding to components of the vitreous body is plausible. Even more so, because after removal of the vitreous body by vitrectomy, no more leptospires are detectable within the eye and the typical symptomatology of ERU remains absent (Wollanke 2002).

- Direct examination of infected tissue reveals bacteria living in cell aggregates or microcolonies surrounded by extracellular matrix. - Leptospires can be visualised by microscopic examination of vitreous samples obtained by vitrectomy from horses affected with ERU. These show single leptospires surrounded by extracellular material (Niedermaier 2002, Brandes et al. 2007) and spherical structures (Brandes et al. 2007), resembling images of leptospiral biofilm in vitro. Ackermann (forthcoming 2021) also succeeded in detecting biofilm matrix surrounding intraocular leptospires by immunohistochemical studies.

- The infection is generally confined to a specific localisation. - The high seroprevalence of leptospiral antibodies in horses indicates that most horses become infected with leptospires during the first few years of life. If intraocular leptospirosis and manifestation of ERU occur, the symptomatology is restricted to the eye alone (Wollanke 2002).

- The infection is impossible or difficult to eliminate by antibiotics, despite the responsible organism's sensitivity to the antibiotics applied in its planktonic state. - Studies on systemic enrofloxacin therapy in horses suffering from ERU showed no significant elimination of the pathogens from the vitreous humour, despite reaching an adequate level of activity (according to MIC and MBC) in the eye (Popp 2011, Popp et al. 2013). Intravitreal gentamicin injection to control leptospires in the eye is a therapeutic method that has been demonstrated to achieve good success rates in terms of freedom from recurrence, according to previous studies (Fischer et al. 2019). Whether this actually eliminates the leptospires from the vitreous humour is unclear. Only a small dose of gentamicin can be safely injected due to the retina-damaging effect of aminoglycosides (Zachary and Forster 1976), therefore, the efficacy in terms of the elimination of bacteria from the vitreous humour is questionable. Currently, there are no long-term results regarding intravitreal gentamicin injection, but it is possible that only short-term therapeutic success might be achieved.

- Culture-negative results, despite a strong suspicion of infection with the pathogen involved. - High antibody titres against leptospires in aqueous and vitreous hu- mour can be detected regularly in eyes affected by ERU. They were produced due to the presence of leptospires in the vitreous humour (Wollanke et al. 2004). Despite the optimisation of culture conditions for leptospires, culture results are positive in only $50 \%$ of vitreous samples tested (Wollanke et al. 2001, Wollanke 2002, Gesell 2004). By comparison, PCR detection from vitreous samples is positive in at least $70 \%$ of cases (Wollanke 2002, Wollanke et al. 2017).

- Ineffective immune defence demonstrated by bacterial cell aggregates surrounded by inflammatory cells in host tissue. - Vitreous samples obtained during vitrectomy show cell aggregates of leptospires only sporadically surrounded by inflammatory cells. This might be due to the fact that vitrectomy is usually not performed during an acute inflammatory episode. Due to the protective mechanisms in the eye against excessive inflammatory reactions, the immunological response is successfully suppressed in the inflammation-free interval, so that an immune reaction in the environment of the leptospiral biofilm cannot be detected by microscopy. Brandes et al. (2007) examined vitreous material from an eye affected with ERU that showed clinical signs of uveitis at the time of vitrectomy. Increased inflammatory cells and free leptospires were detected, some of which had also been phagocytosed.

The theory of the biofilm-associated pathogenesis of ERU may also provide answers to further questions about phenomena that are yet to be explained. Some of these questions are stated below. For a complete review, see Geißler (2021).

- The first appearance of clinical symptoms can occur months or even years after the initial infection both in ERU and chronic wounds, where subclinical infection and biofilm formation occur after bacterial contamination (Percival 2017). Is the long incubation period between primary infection with leptospires and the first appearance of clinical symptoms of ERU (Williams et al. 1971) similarly associated with silent proliferation and biofilm formation?

- Could intraocular biofilm formation explain the persistence of leptospires in the vitreous humour, which is detectable even after numerous bouts of inflammation in eyes affected by ERU (Wollanke 2002)?

- Is it, therefore, possible that only planktonic leptospires are eliminated in the course of uveitis attacks, while leptospires in the biofilm remain undetected by the immune system?

- Is the progressive damage to internal ocular structures occurring as ERU develops (Gerhards and Wollanke 2001) the type of immune-mediated damage that is commonly caused in the presence of a biofilm (Wolcott et al. 2008, Bjarnsholt et al. 2009, Hall-Stoodley et al. 2012, Kinane et al. 2017)?

\section{Conclusion}

When comparing ERU with biofilm-associated infections, numerous parallels in pathogenesis, diagnostics and therapy can be observed. Previous studies of vitreous material from horses suffering from ERU strongly indicate intraocular biofilm 
formation by leptospires or could even show it repeatedly. At this point, the formation of biofilm in the equine vitreous humour appears to be an explanation for both the persistence of leptospires in the eye and the chronic recurrent course of the disease.

Research on the aetiology of ERU and the involvement of intraocular leptospiral biofilm is still in progress. While vitrectomy has already been established as a successful therapeutic method for ERU, knowledge of the involvement of leptospiral biofilm may further support this therapeutic approach - the mechanical removal of the causative pathogen in biofilm-associated infections. Future studies in the area of biofilm formation may provide further insights in the years to come and might also provide the basis for alternative and less invasive treatment options.

\section{References}

Ackermann K. (forthcoming 2021) Darstellung von Leptospiren und deren Biofilmbildung in Glaskörperproben aus an equiner rezidivierender Uveitis erkrankten Augen. Diss. Med. Vet. Munich

Baake E., Von Borstel M., Rohn K., Boevé M. H., Ohnesorge B. (2019) Long-term ophthalmologic examinations of eyes with equine recurrent uveitis after pars plana vitrectomy. Pferdeheilkunde 35, 220-233; DOI 10.21836/PEM20190303

Bessa L. J., Fazii P., Di Giulio M., Cellini L. (2015) Bacterial isolates from infected wounds and their antibiotic susceptibility pattern: some remarks about wound infection. Int. Wound J. 12, 4752; DOI 10.1111/iwj.12049

Billings N., Millan M., Caldara M., Rusconi R., Tarasova Y., Stocker R., Ribbeck K. (2013) The extracellular matrix component Psl provides fast-acting antibiotic defense in Pseudomonas aeruginosa biofilms. PLoS Pathog. 9, e1003526; DOI 10.1371/journal. ppat. 1003526

Bishop P. N. (2000) Structural macromolecules and supramolecular organisation of the vitreous gel. Prog. Retin. Eye Res. 19, 323344; DOI 10.1016/s1350-9462(99)00016-6

Bjarnsholt T., Jensen P., Fiandaca M. J., Pedersen J., Hansen C. R., Andersen C. B., Pressler T., Givskov M., Høiby N. (2009) Pseudomonas aeruginosa biofilms in the respiratory tract of cystic fibrosis patients. Pediatr. Pulmonol. 44, 547558; DOI 10.1002/ ppul.21011

Boles B. R., Singh P. K. (2008) Endogenous oxidative stress produces diversity and adaptability in biofilm communities. Proc. Natl. Acad. Sci. U S A 105, 12503-12508; DOI 10.1073/pnas.0801499105

Brandes, K. (2006) Personal communication.

Brandes K., Wollanke B., Niedermaier G., Brem S., Gerhards H. (2007) Recurrent uveitis in horses: vitreal examinations with ultrastructural detection of leptospires. J. Vet. Med. A Physiol. Pathol. Clin. Med. 54, 270-275; DOI 10.1111/i.1439-0442.2007.00921.x

Brinkmann V., Reichard U., Goosmann C., Fauler B., Uhlemann Y., Weiss D. S., Weinrauch Y., Zychlinsky A. (2004) Neutrophil extracellular traps kill bacteria. Science 303 (5663), 1532-1535; DOI 10.1126/science. 1092385

Chiang W. C., Nilsson M., Jensen P., Høiby N., Nielsen T. E., Givskov M., Tolker-Nielsen T. (2013) Extracellular DNA shields against aminoglycosides in Pseudomonas aeruginosa biofilms. Antimicrob. Agents. Chemother. 57, 2352-2361; DOI 10.1 128/aac.00001-13

Clutterbuck A., Woods E., Knottenbelt D., Clegg P., Cochrane C., Percival S. (2007) Biofilms and their relevance to veterinary medicine. Vet. Microbiol. 121, 1-17; DOI 10.1016/j.vetmic.2006.12.029

Costerton J. W., Cheng K. J., Geesey G. G., Ladd T. I., Nickel J. C., Dasgupta M., Marrie T. J. (1987) Bacterial biofilms in nature and disease. Annu. Rev. Microbiol. 41, 435-464; DOI 10.1146/annurev.mi.41.100187.002251
Costerton J. W., Stewart P. S., Greenberg E. P. (1999). Bacterial biofilms: a common cause of persistent infections. Science 284 (5418), 1318-1322; DOI 10.1126/science.284.5418.1318

Deeg C. A. (2008). Ocular immunology in equine recurrent uveitis. Vet. Ophthalmol. 11, 61-65; DOI 10.1111/j.14635224.2008.00625.x

Deeg C. A., Ehrenhofer M., Thurau S., Reese S., Wildner G., Kaspers B. (2002a) Immunopathology of recurrent uveitis in spontaneously diseased horses. Exp. Eye Res. 75, 127-133

Deeg C. A., Kaspers B., Gerhards H., Thurau S. R., Wollanke B., Wildner G. (2001) Immune responses to retinal autoantigens and peptides in equine recurrent uveitis. Invest. Ophthalmic. Vis. Sci. 42, 393-398

Deeg C. A., Thurau S. R., Gerhards H., Ehrenhofer M., Wildner G., Kaspers B. (2002b) Uveitis in horses induced by interphotoreceptor retinoid-binding protein is similar to the spontaneous disease. Eur. J. Immunol. 32, 2598-2606; DOI 10.1002/15214141 (200209)32:9 < 2598::Aid-immu2598 > 3.0.Co;2-\#

Del Pozo J. L. (2018) Biofilm-related disease. Expert. Rev. Anti. Infect. Ther. 16, 51-65; DOI 10.1080/14787210.2018.1417036

Donaldson S. H., Boucher R. C. (2003) Update on pathogenesis of cystic fibrosis lung disease. Curr. Opin. Pulm. Med. 9, 486-491; DOI 10.1097/00063198-200311000-00007

Donlan R. M., Costerton J. W. (2002) Biofilms: survival mechanisms of clinically relevant microorganisms. Clin. Microbiol. Rev. 15, 167-193; DOI 10.1128/cmr.15.2.167-193.2002

Dowsett C. (2013) Biofilms: A practice-based approach to identification and treatment. Wounds UK 9, 68-72

Ferris R. A., McCue P. M., Borlee G. I., Glapa K. E., Martin K. H., Mangalea M. R., Hennet M. L., Wolfe L. M., Broeckling C. D., Borlee B. R. (2017) Model of chronic equine endometritis involving a Pseudomonas aeruginosa biofilm. Infect. Immun. 85, e0033217; DOI 10.1128/iai.00332-17

Ferris R. A., McCue P. M., Borlee G. I., Loncar K. D., Hennet M. L., Borlee B. R. (2016) In vitro efficacy of nonantibiotic treatments on biofilm disruption of gram-negative pathogens and an in vivo model of infectious endometritis utilizing isolates from the equine uterus. J. Clin. Microbiol. 54, 631-639; DOI 10.1128/ icm.02861-15

Fingerhut L., Ohnesorge B., von Borstel M., Schumski A., Strutzberg-Minder K., Mörgelin M., Deeg C. A., Haagsman H. P., Beineke A., von Köckritz-Blickwede M., de Buhr N. (2019) Neutrophil extracellular traps in the pathogenesis of equine recurrent uveitis (ERU). Cells 8, 1528; DOI 10.3390/cells8121528

Fischer B. M., McMullen R. J., Jr., Reese S., Brehm W. (2019) Intravitreal injection of low-dose gentamicin for the treatment of recurrent or persistent uveitis in horses: preliminary results. BMC Vet. Res. 15, 29; DOI 10.1186/s12917-018-1722-7

Flemming H.-C., Wingender J. (2001) Biofilme - die bevorzugte Lebensform der Bakterien: Flocken, Filme und Schlämme. Biol. Unserer Zeit 31, 169-180.; DOI 10.1002/1521415x(200105)31:3< 169::Aid-biuz169> 3.0.Co;2-u

Fong J. N. C., Yildiz F. H. (2015) Biofilm matrix proteins. Microbiol. Spectr. 3, DOI 10.1128/microbiolspec.MB-0004-2014

Geißler P. K. (2021) Biofilm-Bildung als Pathogenitätsmechanismus bei persistierenden Infektionen und ihre mögliche Rolle bei der Equinen Rezidivierenden Uveitis. Diss. Med. Vet. Munich

Gerhards H., Wollanke B. (2001) Uveitis bei Pferden - Diagnose und Therapie. Pferdeheilkunde 17, 319-329; DOI 10.21836/ PEM20010402

Gesell S. (2004) Gibt es eine asymptomatische intraokulare Leptospireninfektion beim Pferd? Diss. Med. Vet. Munich

Gibson R. L., Burns J. L., Ramsey B. W. (2003) Pathophysiology and management of pulmonary infections in cystic fibrosis. Am. J. Respir. Crit. Care Med. 168, 918-951; DOI 10.1164/rccm.200304-505SO

Gilger B., Deeg C. (2011) Equine Recurrent Uveitis. Equine Ophthalmology. 2nd edition, Gilger, B. (ed.), 317-349; DOI 10.1016/ B978-1-4377-0846-2.00008-2 
Gilger B. C., Michau T. M. (2004) Equine recurrent uveitis: new methods of management. Vet. Clin. North Am. Equine Pract. 20, 417427, vii; DOI 10.1016/j.cveq.2004.04.010

Goldstein S. F., Charon N. W. (1988) Motility of the spirochete Leptospira. Cell Motil. Cytoskeleton 9, 101-110; DOI 10.1002/ cm.970090202

Hall C. W., Mah T. F. (2017) Molecular mechanisms of biofilm-based antibiotic resistance and tolerance in pathogenic bacteria. FEMS Microbiol. Rev. 41, 276-301; DOI 10.1093/femsre/fux010

Hall-Stoodley L., Stoodley P. (2009) Evolving concepts in biofilm infections. Cell Microbiol. 11, 1034-1043; DOI 10.1111/j.14625822.2009.01323.x

Hall-Stoodley L., Stoodley P., Kathiu S., Høiby N., Moser C., Costerton J. W., Moter A., Bjarnsholt T. (2012) Towards diagnostic guidelines for biofilm-associated infections. FEMS Immunol. Med. Microbiol. 65, 127-145; DOI 10.1111/j.1574-695X.2012.00968.x

Hentzer M., Teitzel G. M., Balzer G. J., Heydorn A., Molin S., Givskov M., Parsek M. R. (2001) Alginate overproduction affects Pseudomonas aeruginosa biofilm structure and function. J. Bacteriol. 183, 5395-5401; DOI 10.1128/ib.183.18.53955401.2001

Hoiby N., Biarnsholt T., Givskov M., Molin S., Ciofu O. (2010) Antibiotic resistance of bacterial biofilms. Int. J. Antimicrob. Agents 35, 322-332; DOI 10.1016/i.ijantimicag.2009.12.011

Hoiby N., Biarnsholt T., Moser C., Bassi G. L., Coenye T., Donelli G., Hall-Stoodley L., Hola V., Imbert C., Kirketerp-Moller K., Lebeaux D., Oliver A., Ullmann A. J., Williams C. (2015) ESCMID guideline for the diagnosis and treatment of biofilm infections 2014. Clin. Microbiol. Infect. 21 (Suppl 1), S1-25; DOI 10.1016/i. cmi.2014.10.024

Høiby N., Ciofu O., Johansen H. K., Song Z., Moser C., Jensen P. Ø., Molin S., Givskov M., Tolker-Nielsen T., Bjarnsholt T. (2011) The clinical impact of bacterial biofilms. Int. J. Oral Sci. 3, 55-65

Huseby M. J., Kruse A. C., Digre J., Kohler P. L., Vocke J. A., Mann E. E., Bayles K. W., Bohach G. A., Schlievert P. M., Ohlendorf D. H., Earhart C. A. (2010) Beta toxin catalyzes formation of nucleoprotein matrix in staphylococcal biofilms. Proc. Natl. Acad. Sci. U S A 107, 14407-14412; DOI 10.1073/pnas.0911032107

Jahoor A., Patel R., Bryan A., Do C., Krier J., Watters C., Wahli W., Li G., Williams S. C., Rumbaugh K. P. (2008) Peroxisome proliferator-activated receptors mediate host cell proinflammatory responses to Pseudomonas aeruginosa autoinducer. J. Bacteriol. 190, 4408-4415; DOI 10.1128/ib.01444-07

Jakubovics N. S., Shields R. C., Rajarajan N., Burgess J. G. (2013) Life after death: the critical role of extracellular DNA in microbial biofilms. Lett. Appl. Microbiol. 57, 467-475; DOI 10.1111/ lam. 12134

Jamal M., Ahmad W., Andleeb S., Jalil F., Imran M., Nawaz M. A., Hussain T., Ali M., Rafiq M., Kamil M. A. (2018) Bacterial biofilm and associated infections. J. Chin. Med. Assoc. 81, 7-11; DOI 10.1016/j.jcma.2017.07.012

James G. A., Swogger E., Wolcott R., Pulcini E., Secor P., Sestrich J., Costerton J. W., Stewart P. S. (2008) Biofilms in chronic wounds. Wound Repair Regen. 16, 37-44; DOI 10.1111/j.1524475X.2007.00321.X

Jennings L. K., Storek K. M., Ledvina H. E., Coulon C., Marmont L. S., Sadovskaya I., Secor P. R., Tseng B. S., Scian M., Filloux A., Wozniak D. J., Howell P. L., Parsek M. R. (2015) Pel is a cationic exopolysaccharide that cross-links extracellular DNA in the Pseudomonas aeruginosa biofilm matrix. Proc. Natl. Acad. Sci. U S A 1 12, 11353-11358; DOI 10.1073/ pnas. 1503058112

Joo H. S., Otto M. (2012) Molecular basis of in vivo biofilm formation by bacterial pathogens. Chem. Biol. 19, 1503-1513; DOI 10.1016/i.chembiol.2012.10.022

Kinane D. F., Stathopoulou P. G., Papapanou P. N. (2017) Periodontal diseases. Nat. Rev. Dis. Primers 3, 17038; DOI 10.1038/ nrdp.2017.38
Kristian S. A., Birkenstock T. A., Sauder U., Mack D., Götz F., Landmann R. (2008) Biofilm formation induces C3a release and protects Staphylococcus epidermidis from $\lg G$ and complement deposition and from neutrophil-dependent killing. J. Infect. Dis. 197, 1028-1035; DOI 10.1086/528992

Lewis K. (2001) Riddle of biofilm resistance. Antimicrob. Agents Chemother. 45, 999-1007; DOI 10.1128/aac.45.4.999. 1007.2001

Malone M., Bjarnsholt T., Cooper R., Fletcher J., Fromantin I., Kirketerp-Mølle K., Schultz G., Wolcott R. (2016) Position document: management of biofilm. Wounds International.

Mathee K., Ciofu O., Sternberg C., Lindum P. W., Campbell J. I. A., Jensen P., Johnsen A. H., Givskov M., Ohman D. E., Søren M., Høiby N., Kharazmi A. (1999) Mucoid conversion of Pseudomonas aeruginosa by hydrogen peroxide: a mechanism for virulence activation in the cystic fibrosis lung. Microbiology 145, 1349-1357; DOI 10.1099/13500872-145-6-1349

Montanaro L., Poggi A., Visai L., Ravaioli S., Campoccia D., Speziale P., Arciola C. R. (2011) Extracellular DNA in biofilms. Int. J. Artif. Organs 34, 824-831; DOI 10.5301/ijao.5000051

Murray G. L. (2015) The molecular basis of leptospiral pathogenesis. Curr. Top. Microbiol. Immunol. 387, 139-185; DOI 10.1007/978-3-662-45059-8_7

Nagler M., Insam H., Pietramellara G., Ascher-Jenull J. (2018) Extracellular DNA in natural environments: features, relevance and applications. Appl. Microbiol. Biotechnol. 102, 6343-6356; DOI 10.1007/s00253-018-9120-4

Niedermaier G. (2000) Personal communication

Niedermaier G. (2002) Elektronenmikroskopische Untersuchung des Glaskörpers des Pferdes mit equiner rezidivierender Uveitis. Diss. Med. Vet. Munich

Papayannopoulos V. (2019) Neutrophils facing biofilms: the battle of the barriers. Cell Host Microbe 25, 477-479; DOI 10.1016/i. chom.2019.03.014

Parsek M. R., Singh P. K. (2003) Bacterial biofilms: an emerging link to disease pathogenesis. Annu. Rev. Microbiol. 57, 677-701; DOI 10.1146/annurev.micro.57.030502.090720

Percival S. (2017) Importance of biofilm formation in surgical infection. Br. J. Surg. 104, 85-94; DOI 10.1002/bjs. 10433

Percival S., Cutting K. (2010) The Microbiology of Wounds. Routledge; DOI 10.1201/9781420079944-c6

Percival S. L., Hill K. E., Williams D. W., Hooper S. J., Thomas D. W., Costerton J. W. (2012) A review of the scientific evidence for biofilms in wounds. Wound Repair Regen. 20, 647-657; DOI 10.1111/j.1524-475X.2012.00836.x

Percival S. L., Malic S., Cruz H., Williams D. W. (2011) Introduction to biofilms. In: Biofilms and Veterinary Medicine, S. Percival, D. Knottenbelt, C. Cochrane (eds.). Springer, Berlin, Heidelberg, 41-68; DOI 10.1007/978-3-642-21289-5_2

Percival S. L., Suleman L. (2015) Slough and biofilm: removal of barriers to wound healing by desloughing. J. Wound Care 24, 498, 500-503, 506-510; DOI 10.12968/jowc.2015.24.11.498

Pier G. B., Coleman F., Grout M., Franklin M., Ohman D. E. (2001) Role of alginate $O$ acetylation in resistance of mucoid Pseudomonas aeruginosa to opsonic phagocytosis. Infect. Immun. 69, 1895-1901; DOI 10.1128/iai.69.3.1895-1901.2001

Popp M. K. (2011) Enrofloxacin im Glaskörper an Equiner rezidivierender Uveitis erkrankter Pferde. Diss. Med. Vet. Munich

Popp M. K., Gerhards H., Wollanke B. (2013) Enrofloxacinkonzentrationen im Glaskörper und im Serum an equiner rezidivierender Uveitis (ERU) erkrankter Pferde nach wiederholter intravenöser Verabreichung. Pferdeheilkunde 29, 574-580; DOI 10.21836/ PEM20130501

Ristow P., Bourhy P., Kerneis S., Schmitt C., Prevost M. C., Lilenbaum W., Picardeau M. (2008) Biofilm formation by saprophytic and pathogenic leptospires. Microbiology 154 (Pt 5), 1309-1317; DOI 10.1099/mic.0.2007/014746-0 
Rohde H., Burdelski C., Bartscht K., Hussain M., Buck F., Horstkotte M. A., Knobloch J. K., Heilmann C., Herrmann M., Mack D. (2005) Induction of Staphylococcus epidermidis biofilm formation via proteolytic processing of the accumulation-associated protein by staphylococcal and host proteases. Mol. Microbiol. 55, 18831895; DOI 10.1111/i.1365-2958.2005.04515.x

Savage V. J., Chopra I., O’Neill A. J. (2013) Staphylococcus aureus biofilms promote horizontal transfer of antibiotic resistance. Antimicrob. Agents Chemother. 57, 1968-1970; DOI 10.1128/ aac.02008-12

Schinagl C. (2017). Pars-Plana-Vitrektomie bei Equiner Rezidivierender Uveitis. Diss. Med. Vet. Munich

Stewart P. S. (1996) Theoretical aspects of antibiotic diffusion into microbial biofilms. Antimicrob. Agents Chemother. 40, 2517-2522; DOI 10.1128/aac.40.11.2517

Stewart P. S., Franklin M. J. (2008) Physiological heterogeneity in biofilms. Nat. Rev. Microbiol. 6, 199-210; DOI 10.1038/nrmicrol838

Stewart P. S., Zhang T., Xu R., Pitts B., Walters M. C., Roe F., Kikhney J., Moter A. (2016) Reaction-diffusion theory explains hypoxia and heterogeneous growth within microbial biofilms associated with chronic infections. NPJ Biofilms Microbiomes 2, 16012; DOI 10.1038/npibiofilms.2016.12

Sutherland I. W. (2001) The biofilm matrix - an immobilized but dynamic microbial environment. Trends Microbiol. 9, 222-227; DOI 10.1016/s0966-842x(01)02012-1

Thibeaux R., Soupé-Gilbert M. E., Kainiu M., Girault D., Bierque E., Fernandes J., Bähre H., Douyère A., Eskenazi N., Vinh J., Picardeau M., Goarant C. (2020) The zoonotic pathogen Leptospira interrogans mitigates environmental stress through cyclic-di-GMP-controlled biofilm production. NPJ Biofilms Microbiomes 6, 24; DOI 10.1038/s41522-020-0134-1

Thurlow L. R., Hanke M. L., Fritz T., Angle A., Aldrich A., Williams S. H., Engebretsen I. L., Bayles K. W., Horswill A. R., Kielian T. (2011) Staphylococcus aureus biofilms prevent macrophage phagocytosis and attenuate inflammation in vivo. J. Immunol. 186, 65856596; DOI 10.4049/jimmunol. 1002794
Vinod Kumar K., Lall C., Vimal Raj R., Vedhagiri K., Vijayachari P. (2016) Molecular detection of pathogenic leptospiral protein encoding gene (lipL32) in environmental aquatic biofilms. Lett. Appl. Microbiol. 62, 311-315; DOI 10.1111/lam.12533

Voelter K., Vial Z., Pot S. A., Spiess B. M. (2020) Leptospiral antibody prevalence and surgical treatment outcome in horses with equine recurrent uveitis (ERU) in Switzerland. Vet. Ophthalmol. 23, 648-658; DOI 10.1111/vop.12767

Vuong C., Voyich J. M., Fischer E. R., Braughton K. R., Whitney A. R., Deleo F. R., Otto M. (2004) Polysaccharide intercellular adhesin (PIA) protects Staphylococcus epidermidis against major components of the human innate immune system. Cell Microbiol. 6, 269-275; DOI 10.1046/i.1462-5822.2004.00367.x

Williams R. D., Morter R. L., Freeman M. J., Lavignette A. M. (1971) Experimental chronic uveitis. Ophthalmic signs following equine leptospirosis. Invest. Ophthalmol. 10, 948-954

Wolcott R. D., Rhoads D. D., Dowd S. E. (2008) Biofilms and chronic wound inflammation. J. Wound Care 17, 333-341; DOI 10.12968/jowc.2008.17.8.30796

Wollanke B. (2002) Die equine rezidivierende Uveitis (ERU) als intraokulare Leptospirose. Habil. Med. Vet. Munich

Wollanke B., Gerhards H., Brem S., Meyer P., Kopp H. (2004) Etiology of equine recurrent uveitis (ERU): autoimmune disease or intraocular leptospiral infection? Pferdeheilkunde 20, 327-340; DOI 10.21836/PEM20040403

Wollanke B., Gerhards H., Kaufmann S. (2017) Investigations on the Borrelia-etiology in equine recurrent uveitis (ERU). Pferdeheilkunde 33, 447-451; DOI 10.21836/PEM20170504

Wollanke B., Rohrbach B. W., Gerhards H. (2001) Serum and vitreous humor antibody titers in and isolation of Leptospira interrogans from horses with recurrent uveitis. J. Am Vet. Med. Assoc. 219, 795-800; DOI 10.2460/javma.2001.219.795

Yamaguchi T., Higa N., Okura N., Matsumoto A., Hermawan I., Yamashiro T., Suzuki T., Toma C. (2018) Characterizing interactions of Leptospira interrogans with proximal renal tubule epithelial cells. BMC Microbiol. 18, 64; DOI 10.1 186/s12866-018-1206-8

Zachary I. G., Forster R. K. (1976) Experimental intravitreal gentamicin. Am. J. Ophthalmol. 82, 604-611; DOI 10.1016/00029394(76)90549-3 